\title{
KARAKTERISTIK REKSA DANA \\ DAN KINERJA REKSA DANA SAHAM DI INDONESIA
}

\author{
Christiana Fara Dharmastuti dan Bernadus Dwiprakasa \\ Unika Atma Jaya Jakarta \\ Email: christiana.fara@atmajaya.ac.id
}

\begin{abstract}
A mutual fund is one of the interesting alternative modes of investment models for the investors that do not have much time, knowledge and expertise in calculating the risk and investment return. This study is aimed to understand the influence of the mutual fund's characteristics: the expense ratio, fund size, turnover ratio, and the mutual fund's age towards the mutual fund's performance in Indonesia. This study has been conducted using the Fixed Effect Model with the White cross-section as the coefficient covariance method at 34 active equity mutual funds that existed in Indonesia during the 2012-2013 period. The result of this study has indicated that the expense ratio and the multi fund's age have a significant negative towards the the equities mutual funds in Indonesia while the fund size and the turnover ratios have a significant positive influence towards the the equity's mutual fund's performance in Indonesia.
\end{abstract}

Key words: equity mutual fund, expense ratio, fund size, turnover ratio, the mutual fund's age, the mutual fund's performance, Sharpe.

\begin{abstract}
Abstrak: Reksa dana merupakan salah satu alternative moda investasi menarik bagi investor yang tidak memiliki banyak waktu, pengetahuan dan keahlian dalam menghitung risiko dan return investasi yang dilakukannya. Penelitian ini bertujuan untuk memahami pengaruh karakteristik reksa dana: expense ratio, fund size, turnover ratio, dan usia reksa dana terhadap kinerja reksa dana saham di Indonesia. Penelitian ini dilakukan dengan menggunakan Fixed Effect Model dengan White cross-section sebagai Coef Covariance Method pada 34 reksa dana saham aktif yang ada di Indonesia dengan periode 2012-2013. Hasil penelitian menunjukkan bahwa expense ratio dan usia reksa dana memiliki pengaruh negatif signifikan terhadap kinerja reksa dana saham di Indonesia. Sedangkan fund size dan turnover ratio memiliki pengaruh positif signifikan terhadap kinerja reksa dana saham di Indonesia. Expense ratio, fund size, turnover ratio, dan usia reksa dana secara simultan mempengaruhi kinerja reksa dana saham di Indonesia.
\end{abstract}

Kata kunci: reksa dana saham, expense ratio, fund size, turnover rasio, usia reksa dana, kinerja reksa dana, Sharpe

\section{PENDAHULUAN}

Terdapat berbagai macam jenis aset keuangan yang dapat dipilih oleh investor untuk menginvestasikan uang yang dimiliki. Menurut Bodie, Kane, dan Marcus (2013) aset keuangan dapat dibedakan menjadi tiga jenis, yaitu utang, ekuitas, dan derivatif. Ketiga jenis aset keuangan ini biasa diperdagangkan di pasar modal. Investor dapat secara langsung menginvestasikan uang yang dimiliki ke dalam aset keuangan tersebut. Namun investasi juga dapat dilakukan tidak secara langsung bagi investor yang tidak memiliki 
banyak waktu, pengetahuan, dan keahlian untuk menghitung risiko investasi yang dilakukan.

Reksa dana merupakan salah satu alternatif investasi bagi investor yang tidak memiliki banyak waktu, pengetahuan, dan keahlian untuk menghitung risiko investasi yang dilakukan. Menurut Undang-Undang Pasar Modal Nomor 8 Tahun 1995 pasal 1, ayat (27): "Reksa dana adalah wadah yang dipergunakan untuk menghimpun dana dari masyarakat pemodal untuk selanjutnya diinvestasikan dalam Portofolio Efek oleh Manajer Investasi." Dari definisi tersebut dapat diartikan bahwa investor mempercayakan uang yang dimiliki kepada Manajer Investasi untuk diinvestasikan ke dalam Portofolio Efek. Melalui Manajer Investasi, investor bisa menginvestasikan uang yang dimiliki ke dalam berbagai bentuk aset keuangan yang disebutkan sebelumnya tanpa perlu dilakukan secara langsung.

Reksadana, sebagai alternatif investasi bagi investor, memiliki beberapa kelebihan yang memudahkan investor yang ingin melakukan investasi di pasar modal. Pertama, reksa dana memiliki tingkat likuiditas yang tinggi dimana investor dapat dengan mudah menjual dan membeli pada harga umum yang berlaku. Kedua, dapat dibagi-bagi dalam pecahan yang lebih kecil. Dua kelebihan ini yang membantu seorang investor untuk meminimalisasi risiko melalui diversifikasi investasi. Ketiga, biaya transaksi relatif murah, stabil, dan seragam. Keempat, risiko yang dihadapi bila dikelola secara rasional dapat memberi kepastian terhadap keuntungan yang diperoleh pada masa yang akan datang (Wibowo, 2011). Lohana (2013) menemukan bahwa di Negara berkembang return dari reksa dana memiliki indeks return yang lebih tinggi dibandingkan pasar meskipun tidak terlalu tinggi. Gumilang dan Subiyantoro (2008), Qamruzzaman (2014) menyatakan bahwa pertumbuhan reksa dana lebih tinggi dari return pasar dan menawarkan keuntungan atas diversifikasi, market timing dan penyeleksian saham.

Beberapa kelebihan yang dimiliki oleh reksa dana menjadi daya tarik bagi investor sebagai alternatif pilihan berinvestasi di pasar modal. Ketertarikan investor untuk menginvestasikan uang yang dimiliki ke dalam reksa dana turut mendorong pertumbuhan reksa dana di Indonesia. Berdasarkan data yang diperoleh dari Statistik Pasar Modal yang disediakan Otoritas Jasa Keuangan, terjadi pertumbuhan pada jumlah reksa dana yaitu sebesar 105,46\%, mencapai 828 reksa dana yang ada di Indonesia pada periode 2006 hingga Juli 2014. Pada periode yang sama, Nilai Aktiva Bersih (NAB) turut mengalami pertumbuhan hingga 312.22\% menjadi Rp212.789.711,15 juta dan Unit Penyertaan (UP) turut mengalami pertumbuhan hingga 251,45\% menjadi $127.013,89$ juta unit penyertaan.

Berdasarkan data Tabel 1 yang diperoleh dari Statistik Pasar Modal yang disediakan Otoritas Jasa Keuangan, per 25 Juli 2014 diketahui porsi Nilai Aktiva Bersih reksa dana saham biasa mencapai Rp89,09 triliun atau sebesar 41,61\% dari total Nilai Aktiva Bersih seluruh reksa dana di Indonesia. Jumlah tersebut sangatlah besar dibandingkan jenis reksa dana terproteksi yang menempati urutan kedua terbesar dengan Nilai Aktiva Bersih mencapai Rp42,75 triliun $(19,97 \%)$ dan reksa dana pendapatan tetap yang menempati urutan ketiga dengan Nilai Aktiva Bersih mencapai Rp31,63 triliun $(14,77 \%)$. Hal ini menunjukkan ketertarikan yang sangat besar terhadap reksa dana saham oleh investor di Indonesia. 
Tabel 1. Kinerja Reksa Dana Konvensional

\begin{tabular}{cccc}
\hline Periode & Jumlah Reksa Dana & NAB (Juta Rupiah) & Jumlah UP Beredar (Juta) \\
\hline 2006 & 403 & $51.620 .077,40$ & $36.140,10$ \\
2007 & 567 & $92.190 .634,60$ & $53.589,97$ \\
2008 & 568 & $73.913 .904,41$ & $60.976,09$ \\
2009 & 605 & $112.086 .342,53$ & $69.985,51$ \\
2010 & 616 & $144.704 .495,34$ & $82.079,77$ \\
2011 & 671 & $167.231 .999,92$ & $98.982,08$ \\
2012 & 754 & $187.591 .770,75$ & $113.714,30$ \\
2013 & 794 & $192.544 .524,23$ & $120.886,85$ \\
$2014 *$ & 828 & $212.789 .711,15$ & $127.013,89$ \\
\hline
\end{tabular}

*Per Juli

Sumber: Statistik Pasar Modal Juli Minggu - 4, (2014), Otoritas Jasa Keuangan

Dalam memilih reksa dana, investor mempertimbangkan kinerja dari reksa dana tersebut pada periode terdahulu. Hal ini dilakukan investor dengan harapan reksa dana yang dibeli akan memiliki kinerja yang baik di masa depan. Menurut Sharpe (1966), Waelan (2009) terdapat persistensi kinerja reksa dana pada periode terdahulu dengan periode di masa depan, meskipun kinerja masa lalu bukan suatu jaminan untuk kinerja masa depan. Kinerja dari reksa dana pada periode terdahulu dapat dijadikan acuan dalam memilih reksa dana yang memiliki prospek masa depan yang baik. Menurut Sharpe (1966), Dewi dan ferdian (2012) kinerja reksa dana dapat diukur dengan ukuran yang mempertimbangkan return dan risk rata-rata (risk-adjusted performance) dengan menggunakan reward-to-variability ratio atau Sharpe Ratio.

Terdapat beberapa faktor yang diduga dapat mempengaruhi kinerja reksa dana. Salah satunya adalah biaya dan komisi reksa dana. Menurut Investment Company Institute (2006) biaya dan komisi menjadi pertimbangan utama investor di Amerika Serikat sebelum membeli reksa dana. Namun di Indonesia, biaya dan komisi yang harus ditanggung oleh investor tidak menjadi pertimbangan utama dalam membeli reksa dana. Mayoritas investor di Indonesia beranggapan bahwa biaya dan komisi reksa dana relatif tidak mahal dan tidak mempengaruhi nilai investasi mereka. Perbedaan ini menunjukkan bahwa investor di Indonesia menganggap biaya dan komisi yang harus ditanggung relatif kecil dan terlampaui oleh tingkat return yang dinikmati oleh investor (Tim Studi Biaya dan Komisi Reksa Dana BAPEPAM-LK, 2010).

Menurut Sharpe (1966), O’Neal dan Page (2000) dan Drew, Stanford, dan Veeraraghavan (2002), expense ratio memiliki pengaruh negatif terhadap kinerja reksa dana. Namun berbeda dengan Ippolito (1989) dan Vijayakumar, Muruganandan, dan Chandra (2012) yang menemukan bahwa expense ratio memiliki pengaruh positif terhadap kinerja reksa dana. Semakin tinggi expense ratio semakin baik pula kinerja reksa dana. 
Faktor lain yang diduga mempengaruhi kinerja reksa dana adalah ukuran reksa dana (fund size). Lin dan Yung (2004) dan Vijayakumar et al. (2012) menemukan bahwa ukuran reksa dana memiliki pengaruh yang positif terhadap kinerja reksa dana. Namun Indro, Jiang, Hu, dan Lee (1999) menemukan bahwa ukuran reksa dana yang dikelola secara aktif memiliki pengaruh positif terhadap kinerja reksa dana hingga mencapai ukuran dana optimal, dimana setelah melewati ukuran dana optimal, ukuran reksa dana akan berpengaruh negatif terhadap kinerja reksa dana. Sedangkan Sing (2007) menemukan bahwa besarnya dana tidak memiliki pengaruh yang signifikan terhadap kinerja reksa dana. Petajisto (2013) berargumentasi bahwa fund size tidak memiliki pengaruh dengan kinerja, karena akan lebih berhubungan tipe dari active management. Chen, et.al (2004) menyatakan bahwa fund size tidak terlalu berdampak kepada kinerja yang lebih penting adalah bagaimana dana tersebut dikelola.

Tingkat perputaran portofolio suatu reksa dana merupakan salah satu informasi yang digunakan oleh investor di Amerika Serikat sebagai pertimbangan sebelum membeli suatu reksa dena (Investment Company Institute, 2006). Petajisto (2013) menyatakan bahwa ketidakefisienan pasar dapat dieksploitasi melalui pemilihan saham-saham yang aktif, pertukaran dan pemilihan saham yang baik oleh active management dapat mempengaruhi dari return. Tingkat perputaran portofolio ini dapat diukur dengan Turnover Ratio. Melalui turnover ratio dapat dilihat pengelolaan aktif dan agresivitas Manajer Investasi dalam mengelola reksa dana (Vijayakumar et al., 2012). Menurut Ippolito (1989) dan O'Neal dan Page (2000), turnover ratio memiliki pengaruh positif terhadap kinerja reksa dana. Sedangkan menurut Elton, Gruber, Das, dan Hlavka (1993) dan Vijayakumar et al. (2012) turnover ratio memiliki pengaruh negatif terhadap kinerja reksa dana.

Usia reksa dana diduga juga memiliki pengaruh terhadap kinerja reksa dana. Semakin tua usia reksa dana semakin baik kinerjanya karena pengalaman yang dimiliki cukup sehingga dapat memberikan return yang diharapkan oleh investor (Winingrum, 2011). Menurut Pulungan (2004), Afza dan Rauf (2009), dan Winingrum (2011) usia reksa dana memiliki pengaruh positif terhadap kinerja reksa dana. Namun menurut O'Neal dan Page (2000), See dan Ruzita (2012) usia reksa dana memiliki pengaruh negatif terhadap kinerja reksa dana.

Berdasarkan fenomena mengenai reksadana saham di Indonesia serta masih adanya riset gap dari penelitian terdahulu, maka akan dilakukan studi lebih lanjut tentang karakteristik reksa dana yang ditinjau dari Expense Ratio, Fund Size, Turnover Ratio, dan Usia Reksa Dana Terhadap Kinerja Reksa Dana Saham di Indonesia.

\section{KAJIAN TEORI}

Menurut Undang-Undang Pasar Modal Nomor 8 Tahun 1995 pasal 1, ayat (27): "Reksa dana adalah wadah yang dipergunakan untuk menghimpun dana dari masyarkat pemodal untuk selanjutnya diinvestasikan dalam Portofolio Efek oleh Manajer Investasi." Sebagai produk dari perusahaan investasi, menurut Bodie et al (2013), reksa dana menjalankan beberapa fungsi penting bagi investor mereka, yaitu: (a) Pencatatan dan administrasi, reksa dana mengeluarkan laporan periodik, mencatat distribusi capital gains, dividen, investasi, dan penebusan, dan mereka mungkin menginvestasikan kembali dividen dan pendapatan bunga untuk para pemegang saham; (b) Diversifikasi dan divisibility, reksa dana memberikan investor kesempatan untuk memiliki bagian saham 
dari berbagai macam sekuritas; (c) Pengelolaan secara professional, reksa dana dapat membantu menganalisa sekuritas dan mengelola portofolio untuk mencapai hasil investasi yang superior bagi investor mereka; (d) Menurunkan biaya transaksi, karena reksa dana bertransaksi dalam jumlah besar, mereka dapat menghemat biaya dan komisi broker.

Qamruzzaman (2014) menyatakan bahwa reksa dana memiliki keuntungan dalam hal variasi, fleksibilitas, diversifikasi dan likuiditas. Reksa dana juga memiliki kapabilitas untuk solusi bagi investor yang memiliki keterbatasan pengetahuan dan sumber untuk memperoleh return yang tinggi dan relative aman dan bagi pasar modal suatu Negara akan memberikan kontribusi yang lebih luas.

Karakterisasi kondisi industri reksa dana menurut Ippolito (1989) dapat disimpulkan menjadi dua. Pertama, kinerja bersih reksa dana dapat melampaui (outperformed) kinerja dari index fund. Hasil penelitian tersebut juga menunjukkan bahwa beban dan biaya yang terafiliasi dengan reksa dana dapat tertutupi oleh hasil reksa dana yang superior. Kesimpulan yang kedua, bahwa reksa dana yang memiliki expense ratio dan turnover ratio yang lebih tinggi dapat menghasilkan return yang lebih besar untuk menutupi biaya penjualan yang ada. Dengan kata lain, expense ratio dan turnover ratio memiliki pengaruh yang positif terhadap kinerja dari reksa dana.

Kinerja reksa dana yang diukur melalui 3 pengukuran kinerja menggunakan ukuran rasio Trenor, Sharpe dan Jensen dinyatakan bahwa return dari reksa dana cenderung lebih besar dari return market index, meskipun tidak terlalu tinggi (Lohana, 2013). Lebih lanjut dinyatakan bahwa secara rata-rata return dari reksa dana public maupun swasta memiliki hasil yang hampir sama.

Indro et al. (1999), yang fokus meneliti pada pengaruh ukuran reksa dana (fund size) terhadap kinerja dari reksa dana. Penelitian ini menghasilkan kesimpulan, bahwa reksa dana yang dikelola secara aktif harus mencapai ukuran dana minimal sebelum mereka bisa memperoleh return yang cukup untuk menutupi biaya informasi dan biaya transaksi perdagangan atas informasi tersebut. Adanya diminishing marginal returns atas aktifitas memperoleh informasi dan marginal returns akan menjadi negatif ketika reksa dana telah melebihi ukuran optimalnya. Dengan demikian ukuran reksa dana yang dikelola secara aktif memiliki pengaruh positif terhadap kinerja reksa dana hingga reksa dana mencapai ukuran dana optimal, dimana setelah melewati ukuran dana optimal, ukuran reksa dana akan berpengaruh negatif terhadap kinerja reksa dana.

Khorana,Servaes dan Tufano (2008), yang meneliti besaran fee yang diterapkan pada 46.580 reksa dana di 18 negara menemukan bahwa management fee, shareholder cost maupun total expenses ratio menjadi hal yang penting dalam peralihan dana antar negara. Besaran fee akan berbeda-beda antar negara tergantung dari tujuan investasi, besaran dana dan kompleksitas pengenaan biaya antar Negara. Lebih lanjut ditemukan bahwa fee dari reksa dana cenderung lebih rendah pada negara yang memiliki system hukum yang kuat, memiliki regulasi yang jelas, GDP yang tinggi, masyarakat berpendidikan tinggi dan konsentrasi sector perbankan tidak terlalu tinggi.

Hipotesis Konseptual. Berdasarkan hasil studi literatur yang telah dilakukan terhadap penelitian terdahulu, terdapat beberapa faktor yang dirasa perlu untuk diteliti kembali untuk mengetahui pengaruhnya terhadap kinerja reksa dana. Adanya research gap dari hasil penelitian terdahulu yang telah dilakukan, mendorong peneliti untuk kembali melakukan penelitian terhadap faktor-faktor yang dapat mempengaruhi kinerja reksa dana sebagai berikut: 
Expense Ratio. Menurut Investment Company Institute (2004) dalam Sing (2007), expense ratio adalah biaya yang dibutuhkan reksa dana untuk menjalankan bisnisnya, diungkapkan di dalam prospektus dan dinyatakan dalam presentase dari aset reksa dana tersebut. Menurut Indro et al (1999), expense ratio adalah proporsi dari aset reksa dana yang dibayarkan untuk biaya operasi dan biaya manajemen, termasuk biaya $12 \mathrm{~b}-1$, biaya administratif, dan biaya lain-lain yang timbul berdasarkan aset namun tidak termasuk biaya broker. Fama dan French (2010) menyatakan bahwa biaya dalam bentuk expenses ratio merupakan cakupan dari keahlian dari manajemen yang aktif Semakin besar expense ratio dari suatu reksa dana, menunjukkan semakin aktifnya pengelolaan dan kegiatan yang dilakukan oleh reksa dana tersebut.

Indro et al. (1999) bahwa expense ratio merefleksikan biaya riset yang dilakukan oleh reksa dana. Semakin besar expense ratio dari suatu reksa dana, semakin besar pula biaya yang dikeluarkan untuk melakukan riset. Dengan adanya kegiatan riset yang lebih baik, diharapkan kinerja reksa dana juga bisa meningkat. Ippolito (1989) dan Vijayakumar et al. (2012) menemukan bahwa expense ratio memiliki pengaruh positif terhadap kinerja reksa dana. Semakin tinggi expense ratio semakin baik pula kinerja reksa dana. Dalam penelitian ini, hipotesis pertama yang diajukan adalah:

$\mathbf{H}_{1}$ : Expense Ratio memiliki pengaruh positif terhadap kinerja reksa dana saham.

Fund Size. Menurut Indro et al. (1999), fund size bisa didefinisikan sebagai logaritma natural dari aset bersih dalam kelolaan pada akhir bulan. Sedangkan menurut Goel et al. (2012) asset size (fund size) adalah total nilai pasar dari seluruh efek yang dimiliki dalam portofolio yang ditunjukkan dalam nilai aset dalam kelolaan (Asset Under Management).

Ukuran reksa dana (fund size) diukur dari nilai aset dalam kelolaan (asset under management) atau nilai aset bersih dalam kelolaan (net asset under management). Semakin besar ukuran reksa dana, semakin besar skala ekonomis yang bisa didapat oleh reksa dana. Reksa dana yang memiliki ukuran besar memiliki volume transaksi yang relatif besar pula, sehingga komisi broker untuk eksekusi perdagangan yang dilakukan oleh reksa dana tersebut dapat ditekan lebih rendah. Lin dan Yung (2004) dan Vijayakumar et al. (2012) menemukan bahwa ukuran reksa dana memiliki pengaruh yang positif terhadap kinerja reksa dana. Dalam penelitian ini, hipotesis kedua yang diajukan adalah:

$\mathbf{H}_{2}$ : Fund Size memiliki pengaruh positif terhadap kinerja reksa dana saham.

Turnover Ratio. Menurut Bodie et al. (2013), turnover ratio adalah rasio aktivitas perdagangan dari suatu portofolio terhadap aset dari portofolio. Turnover ratio yang didefinisikan oleh Centre for Research and Security Prices dalam Goel et al (2012) adalah agregat minimum dari penjualan atau pembelian efek, dibagi dengan rata-rata 12 bulan total aset bersih reksa dana. Turnover ratio ditunjukkan dalam bentuk presentase dari aset reksa dana.

Melalui turnover ratio dapat dilihat pengelolaan aktif dan agresivitas Manajer Investasi dalam mengelola reksa dana (Vijayakumar et al., 2012). Melalui turnover ratio juga dapat dilihat kebijakan strategi investasi yang ditetapkan oleh Manajer Investasi (Indro et al. 1999).

Berdasarkan penelitian yang sudah dilakukan sebelumnya, turnover ratio memiliki pengaruh terhadap kinerja reksa dana. Menurut Ippolito (1989) dan O'Neal dan Page (2000), turnover ratio memiliki pengaruh positif terhadap kinerja reksa dana. Pengaruh 
turnover ratio terhadap kinerja reksa dana dikuatkan melalui efficient market theory. Efficient market theory menyatakan bahwa aktifitas perdagangan seharusnya tidak meningkatkan net returns suatu portofolio. Namun, jika aktivitas manajemen dapat meningkatkan net returns reksa dana, maka net returns tersebut berkaitan langsung dengan portfolio turnover (Philpot, Hearth, Rimbey, dan Schulman, 1998). Dalam penelitian ini, hipotesis ketiga yang diajukan adalah:

$\mathbf{H}_{3}$ : Turnover ratio memiliki pengaruh positif terhadap kinerja reksa dana saham.

Usia Reksa Dana. Menurut Winingrum (2011) usia dari reksa dana mengindikasikan kapan suatu reksa dana mulai diperdagangkan di pasar modal. Usia reksa dana dapat ditentukan dari tanggal efektif reksa dana tersebut. Menurut O'Neal dan Page (2000) usia reksa dana dapat ditentukan berdasarkan usia sejak lahirnya reksa dana tersebut.

Semakin tua usia reksa dana semakin baik kinerjanya karena pengalaman yang dimiliki cukup sehingga dapat memberikan return yang diharapkan oleh investor (Winingrum, 2011). Menurut Afza dan Rauf (2009), dan Winingrum (2011) usia reksa dana memiliki pengaruh positif terhadap kinerja reksa dana. Dalam penelitian ini, hipotesis keempat yang diajukan adalah:

$\mathbf{H}_{\mathbf{4}}$ : Usia Reksa Dana memiliki pengaruh positif terhadap kinerja reksa dana saham.

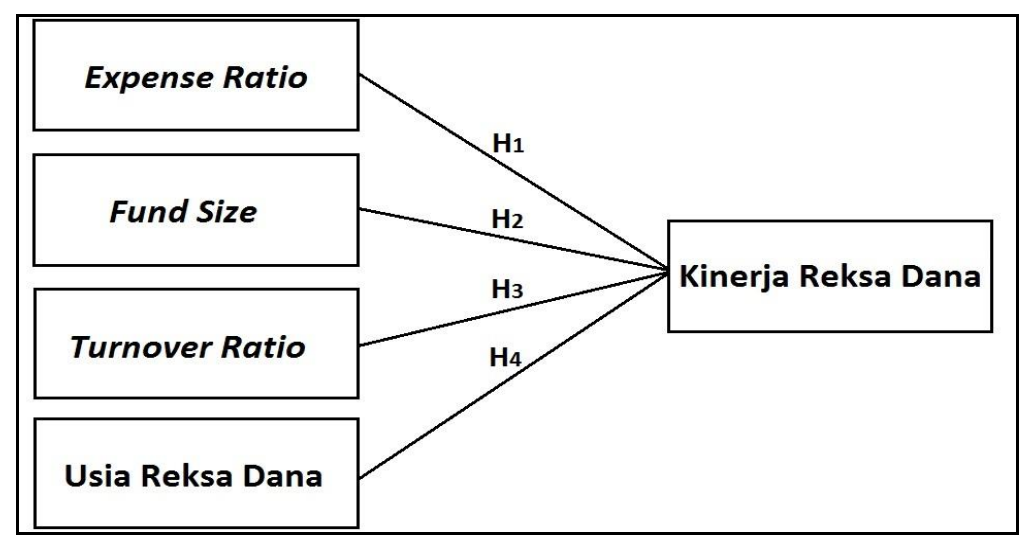

Gambar 1. Model penelitian

\section{METODE}

Data yang digunakan dalam penelitian ini bersumber dari laporan keuangan reksa dana saham yang terdapat di dalam prospektus pembaharuan reksa dana saham periode 20122013. Prospektus pembaharuan ini didapat dari Manajer Investasi yang mengelola reksa dana terkait dan Agen Penjual yang menawarkan reksa dana terkait. Data tersebut dapat diakses melalui situs Manajer Investasi atau menghubungi Manajer Investasi terkait.

Untuk data Nilai Aktiva Bersih (NAB) per unit harian dari reksa dana saham terkait periode 2012-2013, diambil dari http://pusatdata.kontan.co.id/reksadana. Sedangkan untuk data Rata-Rata Suku Bunga Bank Indonesia (BI Rate) yang digunakan sebagai acuan aset bebas risiko di Indonesia (risk free asset) periode 2012-2013, diambil dari www.bi.go.id.

Populasi penelitian adalah seluruh reksa dana saham aktif di Indonesia pada periode 20122013. Dipilih 34 reksa dana saham sebagai sampel penelitian dengan kriteria pemilihan sebagai berikut: (1) Reksa dana memiliki laporan keuangan reksa dana untuk periode 
2012-2013 yang dapat diakses; (2) Reksa dana memiliki prospektus pembaharuan reksa dana untuk periode 2012-2013 yang dapat diakses; (3) Reksa dana memiliki data historis NAB per unit harian untuk periode 2012-2013 yang dapat diakses.

Definisi Operasional Variabel. Penelitian ini akan menganalisis pengaruh expense ratio, fund size, turnover ratio, dan usia reksa dana terhadap kinerja reksa dana. Variabel dependen dalam penelitian ini, yaitu kinerja reksa dana, berupa risk-adjusted return dari reksa dana. Kinerja reksa dana akan diukur dengan menggunakan pendekatan yang dilakukan oleh Sharpe (1966). Semakin besar nilai angka hasil perhitungan menggunakan pendekatan Sharpe, semakin baik kinerja dari reksa dana. Pendekatan Sharpe dapat diformulasikan sebagai berikut (Bodie et al., 2013; Dewi dan Ferdian, 2012):

$$
S p=\frac{R p-R f}{\sigma p}
$$

Dimana:

$\mathrm{Sp} \quad=$ nilai pengukuran Sharpe untuk suatu periode tertentu

$\mathrm{Rp} \quad=$ total return portofolio selama suatu periode tertentu

Rf = tingkat return aset yang bebas risiko selama suatu periode tertentu

$\mathrm{p} \quad=$ standar deviasi dari portofolio selama suatu periode tertentu.

\section{Variabel Independen}

1. Expense Ratio. Dari berbagai jurnal yang telah dipaparkan sebelumnya, dapat disimpulkan bahwa expense ratio adalah rasio biaya operasional yang dibutuhkan reksa dana untuk menjalankan aktivitasnya dan dibebankan kepada aset dari reksa dana tersebut. Expense ratio dinyatakan dalam prospektus reksa dana dalam bentuk presentase dari aset reksa dana tersebut.

2. Fund Size. Fund size adalah total nilai pasar dari seluruh efek yang dimiliki dalam portofolio reksa dana yang ditunjukkan dalam nilai aset dalam kelolaan (Goel et al., 2012). Fund size dalam penelitian ini akan dilihat dari nilai aset bersih dalam kelolaan (net assets under management) reksa dana, yang diperoleh dari laporan keuangan reksa dana.

3. Turnover Ratio. Turnover ratio adalah rasio aktivitas perdagangan dari suatu portofolio terhadap aset dari portofolio (Bodie et al., 2013). Turnover ratio ditunjukkan dalam bentuk presentase dari aset reksa dana dalam prospektus reksa dana.

4. Usia Reksa Dana. Usia reksa dana menggambarkan waktu yang telah dilewati oleh reksa dana dari sejak lahirnya reksa dana hingga berakhirnya reksa dana tersebut. Dalam penelitian ini, usia reksa dana ditentukan berdasarkan tanggal efektif reksa dana tersebut sampai dengan tahun penelitian yang dimaksud, yaitu 2012 dan 2013.

Metode Analisis Data. Penelitian ini dilakukan dengan menggunakan data panel, yaitu gabungan antara data time series dan cross-section. Dalam data panel, ada 3 model penelitian yang bisa digunakan, yaitu Pooled Least Square (PLS), Fixed Effect Model (FEM), dan Random Effect Model (REM). Untuk menentukan metode yang paling tepat untuk mengestimasi data panel, dilakukan pengujian Chow Test dan Hausman Test. 
Untuk menguji hipotesis penelitian mengenai pengaruh setiap variabel independen terhadap variabel dependen dilakukan dengan menggunakan uji-t statistik. Dalam penelitian ini, uji-t statistik diproses dengan bantuan program EViews 6 .

\section{ANALISIS DAN PEMBAHASAN}

Analisis Statistik Deskriptif

Tabel 2. Statistik Deskriptif

\begin{tabular}{lrrrrr}
\hline & $\mathrm{N}$ & Minimum & Maximum & Mean & Std. Deviation \\
\hline EXPENSE & 68 & $0.25 \%$ & $9.78 \%$ & $3.6962 \%$ & $1.55498 \%$ \\
FUND SIZE & 68 & 9432842091.00 & 8817207397411.00 & 1231024481232.53 & 1799213267269.22 \\
TURNOVER & 68 & 0.01 & 12.02 & 1.5716 & 1.75599 \\
FUND AGE & 68 & 0.384 & 17.43 & 8.10 & 4.545 \\
SHARPE & 68 & -0.1384 & 0.1321 & -0.0231 & 0.0756 \\
Valid N & 68 & & & & \\
(listwise) & & & & & \\
\hline
\end{tabular}

Analisis deskriptif dilakukan terhadap 68 data yang valid pada setiap variabel penelitian. Dari analisis yang dilakukan, diketahui bahwa variabel independen expense ratio (expense) memiliki nilai minimum sebesar $0,25 \%$ yang dimiliki oleh reksa dana Mandiri Dynamic Equity periode 2012. Sedangkan nilai maksimum dari variabel expense ratio dimiliki oleh reksa dana PNM Ekuitas Syariah periode 2013 dengan nilai sebesar 9,78\%. Rata-rata reksa dana saham memiliki expense ratio sebesar 3,6962\%.

Pada variabel independen fund size (fund size), didapat nilai minimum sebesar Rp9.432.842.091,00 yang dimiliki oleh reksa dana Batavia Dana Saham Agro periode 2013. Sedangkan nilai maksimum sebesar Rp8.817.207.397.411,00, dimiliki oleh reksa dana Schroder Dana Prestasi Plus periode 2012. Rata-rata fund size yang dimiliki oleh reksa dana saham adalah sebesar Rp1.231.024.481.232.53.

Pada variabel independen turnover ratio (turnover), didapat nilai minimum sebesar 0,01 yang dimiliki oleh reksa dana NISP Indeks Saham Progresif periode 2012. Sedangkan nilai maksimum sebesar 12,02, dimiliki oleh reksa dana PNM Ekuitas Syariah periode 2013. Rata-rata turnover ratio yang dimiliki oleh reksa dana saham adalah sebesar 1,5716 .

Pada variabel independen terakhir dalam penelitian ini, yaitu usia reksa dana (fund age), nilai minimum yang didapat adalah sebesar 0,384tahun (140 hari) yang dimiliki oleh reksa dana Mandiri Dynamic Equity periode 2012. Sedangkan untuk nilai maksimum sebesar 17,43 tahun, dimiliki oleh reksa dana Bahana Dana Prima periode 2013. Rata-rata usia reksa dana yang dimiliki oleh reksa dana saham adalah sebesar 8,10 tahun.

Variabel dependen Sharpe Ratio (Sharpe) memiliki nilai minimum sebesar -0,1384 dimiliki oleh reksa dana TRIM Kapital Plus periode 2013. Sedangkan untuk nilai Sharpe Ratio maksimum sebesar 0,1321 dimiliki oleh reksa dana BNP Paribas Pesona Syariah periode 2012. Nilai rata-rata Sharpe Ratio didapat sebesar -0,0231.

Estimasi Model Data Panel. Untuk menentukan metode yang paling tepat untuk mengestimasi data panel, diperlukan serangkaian pengujian. 
Tabel 3. Hasil Pengujian Chow Test

Redundant Fixed Effects Tests

Pool: Untitled

Test cross-section fixed effects

\begin{tabular}{cccc}
\hline \hline Effects Test & Statistic & d.f. & Prob. \\
\hline \hline Cross-section F & 4.682530 & $(33,30)$ & 0.0000 \\
Cross-section Chi-square & 123.527400 & 33 & 0.0000 \\
\hline \hline
\end{tabular}

Pengujian dengan menggunakan Chow Test perlu dilakukan untuk menentukan metode yang lebih baik dalam mengestimasi data panel antara Pooled Model dengan Fixed Effect Model. Dari hasil pengujian dengan menggunakan Chow Test didapat p-value crosssection Chi-square sebesar 0,0000, lebih kecil dibandingkan dengan tingkat signifikansi sebesar 5\%. Hasil pengujian ini menunjukkan model yang lebih cocok digunakan dalam penelitian ini adalah Fixed Effect Model.

Tabel 4. Hasil Pengujian Hausman Test

Correlated Random Effects - Hausman Test

Pool: Untitled

Test cross-section random effects

\begin{tabular}{lcrrr}
\hline \hline Test Summary & Chi-Sq. Statistic & Chi-Sq. d.f. & Prob. \\
\hline \hline & & & & \\
Cross-section random & 0.000000 & 4 & 1.0000 \\
\hline \hline
\end{tabular}

Untuk memastikan bahwa Fixed Effect Model merupakan model terbaik untuk penelitian ini, diperlukan pengujian menggunakan Hausman Test untuk membandingkannya dengan Random Effect Model. Dari hasil pengujian menggunakan Hausman Test, didapat $p$-value dari cross-section random sebesar 1,0000, yang berarti pengujian dengan Hausman Test tidak valid sehingga tidak dapat ditentukan model yang tepat antara Fixed Effect Model dengan Random Effect Model yang akan digunakan untuk penelitian ini.

Untuk mengatasi masalah di atas, terdapat beberapa pertimbangan teknis dan empiris yang dapat dijadikan panduan dalam menentukan model yang tepat untuk penelitian ini. Berdasarkan pertimbangan bahwa jumlah $\mathrm{N}$ lebih besar daripada $\mathrm{T}$, dan unit cross-section dipilih berdasarkan kriteria tertentu maka lebih tepat menggunakan Fixed Effect Model, Gujarati (2003) dalam Haninditya (2011),

Estimasi Data Panel Menggunakan Fixed Effect Model. Berdasarkan hasil pengujian model terbaik untuk penelitian ini yang telah dilakukan, Fixed Effect Model dengan menggunakan White cross-section sebagai Coef Covariance Method digunakan untuk 
mengestimasi data panel dalam penelitian ini. Hasil estimasi data panel yang diproses menggunakan program EViews 6 ditunjukkan dalam Tabel 5.

Tabel 5. Hasil Estimasi Menggunakan Fixed Effect Model (White cross-section sebagai Coef Covariance Method)

\begin{tabular}{ccrrr}
\hline \hline Variable & Coefficient & Std. Error & t-Statistic & Prob. \\
\hline \hline C & 0.947175 & $4.08 \mathrm{E}-13$ & $2.32 \mathrm{E}+12$ & 0.0000 \\
EXPENSE? & -2.658888 & $6.78 \mathrm{E}-12$ & $-3.92 \mathrm{E}+11$ & 0.0000 \\
AGE? & -0.114957 & $2.67 \mathrm{E}-15$ & $-4.31 \mathrm{E}+13$ & 0.0000 \\
FUND? & $5.15 \mathrm{E}-15$ & $2.57 \mathrm{E}-26$ & $2.01 \mathrm{E}+11$ & 0.0000 \\
TURNOVER? & 0.033687 & $5.25 \mathrm{E}-14$ & $6.41 \mathrm{E}+11$ & 0.0000 \\
& & & \\
\hline \hline
\end{tabular}

Cross-section fixed (dummy variables)

\begin{tabular}{lllr}
\hline \hline R-squared & 0.840910 & Mean dependent var & -0.023097 \\
Adjusted R-squared & 0.644698 & S.D. dependent var & 0.075580 \\
S.E. of regression & 0.045051 & Akaike info criterion & -3.062695 \\
Sum squared resid & 0.060888 & Schwarz criterion & -1.822382 \\
Log likelihood & 142.1316 & Hannan-Quinn criter. & -2.571245 \\
F-statistic & 4.285732 & Durbin-Watson stat & 3.885714 \\
Prob(F-statistic) & 0.000049 & & \\
\hline \hline
\end{tabular}

Berdasarkan hasil estimasi tersebut, didapati bahwa adjusted $R$-squared dari model yang digunakan adalah sebesar 64,47\% (0,644698). Berarti dapat diartikan bahwa 64,47\% dari variasi dalam variabel dependen (Sharpe Ratio) dapat dijelaskan oleh variasi dalam variabel independen dalam penelitian ini (expense ratio, fund size, turnover ratio, dan usia reksa dana). Sedangkan 35,53\% dijelaskan oleh variabel lain yang tidak dimasukkan di dalam penelitian ini.

Selanjutnya untuk menguji signifikansi secara simultan dari model dapat dilihat dari p-value dari F-statistic yang didapati sebesar 0,000049. Hasil ini lebih rendah bila dibandingkan dengan tingkat signifikansi sebesar 5\%. Berarti dapat diartikan bahwa variabel independen yang terdapat di dalam model penelitian secara simultan mempengaruhi variabel dependen dalam penelitian.

Selanjutnya untuk menguji pengaruh masing-masing variabel independen terhadap variabel dependen di dalam penelitian ini dapat dilihat dari $p$-value dari $t$-statistic masingmasing variabel independen. Dengan tingkat signifikansi sebesar 5\% yang digunakan dalam penelitian ini, maka dapat diartikan sebagai berikut:

Pengaruh Expense Ratio Terhadap Kinerja Reksa Dana Saham. Berdasarkan hasil estimasi data yang telah dilakukan dapat disimpulkan bahwa expense ratio secara signifikan mempengaruhi kinerja reksa dana saham yang diukur dengan menggunakan Sharpe Ratio. Hanya saja penemuan ini berbeda dengan hasil penelitian terdahulu yang 
dilakukan oleh Ippolito (1989) dan Vijayakumar et al. (2012) serta hipotesis yang diajukan dalam penelitian ini. Hasil estimasi menunjukkan bahwa expense ratio memiliki pengaruh negatif signifikan terhadap kinerja reksa dana saham.

Penemuan dari penelitian ini selaras dengan hasil dari penelitian sebelumnya yang telah dilakukan oleh Sharpe (1966), O’Neal dan Page (2000), Drew et al. (2002) dan Chen,et.al(2004), bahwa expense ratio memiliki pengaruh negatif terhadap kinerja reksa dana. Menurut Sharpe (1966), jika pasar sangat efisien, reksa dana yang mengeluarkan biaya paling sedikit yang seharusnya menunjukkan kinerja paling baik. Jika pasar tidak efisien, reksa dana yang mengeluarkan biaya lebih banyak, mungkin dapat meraih return yang lebih besar dari sekedar menutup peningkatan biaya yang dikeluarkan, sehingga menunjukkan kinerja yang lebih baik. Khorana, et al (2008) menambahkan bahwa pada negara yang sudah mapan, dengan regulasi yang baik, system hukum yang baik serta kondisi masyarakat yang baik dan industry keuangan yang mapan memiliki kecenderungan fee yang lebih rendah.

Sedangkan menurut Fama dan French (2010) kinerja reksa dana dari penyesuaian return yang diharapkan akan menurun akibat adanya penyesuaian atas biaya yang dibebankan untuk menanggung biaya dari active management.

Pengaruh Fund Size Terhadap Kinerja Reksa Dana Saham. Berdasarkan hasil estimasi data yang telah dilakukan dapat disimpulkan bahwa fund size secara positif signifikan mempengaruhi kinerja reksa dana saham yang diukur dengan menggunakan Sharpe Ratio. Penemuan ini sesuai dengan hipotesis yang diajukan dalam penelitian ini, bahwa fund size memiliki pengaruh positif terhadap kinerja reksa dana saham. Penemuan ini juga turut mendukung hasil penelitian terdahulu yang dilakukan oleh Lin dan Yung (2004), Gumilang dan Subiyantoro (2008), Vijayakumar et al. (2012) mengenai pengaruh positif fund size terhadap kinerja reksa dana saham.

Menurut Vijayakumar et al. (2012) semakin besar ukuran reksa dana, ada kecenderungan reksa dana menjadi semakin efisien. Menurut Lin dan Yung (2004), ukuran reksa dana (fund size) yang lebih besar memiliki skala ekonomis yang lebih besar juga. Reksa dana yang memiliki ukuran besar mampu melakukan riset yang lebih baik dan mampu untuk mendapatkan manajer portofolio yang lebih baik juga. Hal ini sesuai dengan yang diungkapkan Sharpe (1966) dalam hubungan antara expense ratio dengan fund size, bahwa reksa dana yang memiliki ukuran yang besar, mampu untuk mendapatkan analisa efek yang lebih baik dengan mengeluarkan biaya dengan presentase yang lebih kecil dari pendapatannya, dibanding dengan reksa dana yang berukuran lebih kecil. Sehingga semakin besar ukuran reksa dana semakin baik kinerja reksa dana tersebut.

Pengaruh Turnover Ratio Terhadap Kinerja Reksa Dana Saham. Berdasarkan hasil estimasi data yang telah dilakukan dapat disimpulkan bahwa turnover ratio secara positif signifikan mempengaruhi kinerja reksa dana saham yang diukur dengan menggunakan Sharpe Ratio. Penemuan ini sesuai dengan hipotesis yang diajukan dalam penelitian ini, bahwa turnover ratio memiliki pengaruh positif terhadap kinerja reksa dana saham. Penemuan ini juga turut mendukung hasil penelitian terdahulu yang dilakukan oleh Ippolito (1989) dan O'Neal dan Page (2000) mengenai pengaruh positif turnover ratio terhadap kinerja reksa dana.

Menurut Fama (1970) dalam Ippolito (1989), efficient market theory dapat diartikan bahwa harga saham merefleksikan seluruh informasi yang tersedia di pasar. Berdasarkan 
teori ini, reksa dana tidak akan bisa meningkatkan kinerjanya dengan melakukan riset dan perdagangan dalam pasar yang sangat efisien. Reksa dana akan terus mengalami penurunan kinerja ketika mengeluarkan lebih banyak sumber daya untuk mencoba mencari harga efek yang tidak sesuai dengan informasi yang tersedia di pasar. Berdasarkan asumsi tersebut, maka bisa dikatakan bahwa pasar di Indonesia tidak efisien. Dengan melakukan riset dan perdagangan secara aktif, manajer portofolio berusaha mencari harga efek yang tidak sesuai dengan informasi yang tersedia di pasar untuk meraih keuntungan atas informasi yang dimilikinya. Perdagangan yang dilakukan oleh manajer portofolio tersebut diukur dengan turnover ratio. Sehingga semakin tinggi turnover ratio semakin baik kinerja dari reksa dana saham di Indonesia. Selaras yang disampaikan Petajisto (2013) untuk pasar yang tidak efisien dapat dieksploitasi melalui pemilihan saham secara aktif yang akan membawa kesuksesan pada return saham.

Pengaruh Usia Reksa Dana Terhadap Kinerja Reksa Dana Saham. Berdasarkan hasil estimasi data yang telah dilakukan dapat disimpulkan bahwa usia reksa dana secara signifikan mempengaruhi kinerja reksa dana saham. Hanya saja penemuan ini berbeda dengan hasil penelitian terdahulu yang dilakukan oleh Afza dan Rauf (2009), dan Winingrum (2011) serta hipotesis yang diajukan dalam penelitian ini. Hasil estimasi menunjukkan bahwa usia reksa dana memiliki pengaruh negatif signifikan terhadap kinerja reksa dana saham.

Terdapat beberapa dugaan mengenai penyebab usia reksa dana memiliki pengaruh negatif signifikan terhadap kinerja reksa dana saham di Indonesia. Peneliti menduga, bahwa reksa dana saham di Indonesia telah memasuki tahapan siklus hidup yang lebih tua seiring dengan bertambahnya usia reksa dana. Semakin tua siklus hidup reksa dana, semakin kecil pertumbuhan yang terjadi, dan kinerja juga akan mengalami penurunan. Dugaan ini sesuai dengan hasil penelitian yang dilakukan oleh Ling (2011), See dan Ruzita (2012) yang menemukan reksa dana dengan umur yang lebih muda memiliki kinerja yang lebih baik daripada reksa dana dengan umur yang lebih tua. Manajer Investasi semakin sulit untuk dapat menginvestasikan aset yang dimiliki ke dalam saham yang undervalued. Pertumbuhan reksa dana yang telah memasuki tahapan siklus hidup yang lebih tua akan semakin rendah, karena Manajer Investasi semakin sulit dalam menemukan kesempatan investasi baru di pasar. Sehingga kinerja reksa dana akan turun seiring dengan bertambahnya usia dan memasuki tahapan siklus hidup yang lebih tua dari reksa dana tersebut.

Dari sisi investor, ada anggapan bahwa reksa dana yang memiliki fund size mencapai triliun rupiah umumnya mengalami pelambatan kinerja, sedangkan reksa dana yang memiliki fund size miliaran rupiah memiliki kinerja yang lebih baik dibandingkan reksa dana yang memiliki fund size triliunan rupiah. Reksa dana dengan fund size triliunan rupiah dikenal dengan istilah trillion club, sedangkan reksa dana dengan fund size miliaran rupiah dikenal dengan istilah billion club (Rudiyanto, 2014).

\section{PENUTUP}

Simpulan. Berdasarkan hasil penelitian yang telah dilakukan untuk mengetahui pengaruh antara variabel independen yaitu expense ratio, fund size, turnover ratio, dan usia reksa dana terhadap variabel dependen yaitu kinerja reksa dana saham di Indonesia yang diukur dengan Sharpe Ratio pada tahun 2012-2013, dapat ditarik beberapa kesimpulan sebagai 
berikut: (1) Expense ratio memiliki pengaruh negatif signifikan terhadap kinerja reksa dana saham di Indonesia. Sehingga, semakin besar biaya yang dikeluarkan oleh reksa dana yang tercermin dalam expense ratio, semakin buruk kinerja reksa dana tersebut; (2) Ukuran reksa dana (fund size) memiliki pengaruh positif signifikan terhadap kinerja reksa dana saham di Indonesia. Sehingga, semakin besar ukuran reksa dana yang tercermin dalam nilai aset bersih dalam kelolaan, semakin baik kinerja reksa dana tersebut; (3) Turnover ratio memiliki pengaruh positif signifikan terhadap kinerja reksa dana saham di Indonesia. Sehingga, semakin besar turnover ratio dari reksa dana, semakin baik kinerja reksa dana tersebut; (4) Usia reksa dana memiliki pengaruh negatif signifikan terhadap kinerja reksa dana saham di Indonesia. Sehingga, semakin tua usia dari suatu reksa dana, semakin buruk kinerja reksa dana tersebut; (5) Bagi penelitian selanjutnya dapat menambahkan variabel independen lainnya, seperti stock selection skill, market timing ability, atau karakteristik reksa dana lainnya, untuk mendapatkan adjusted $R$-square yang lebih baik dibandingkan dalam penelitian ini. Khusus untuk variabel independen usia reksa dana, penelitian selanjutnya sebaiknya meneliti dengan rentang waktu yang lebih panjang dan jumlah reksa dana yang lebih banyak agar didapat hasil yang lebih baik mengenai pengaruh variabel tersebut terhadap kinerja reksa dana saham di Indonesia.

\section{DAFTAR RUJUKAN}

Afza, T., \& Rauf, A. (2009) "Performance Evaluation of Pakistani Mutual Funds". Pakistan Economic and Social Review. 47 (2), 199-214.

Bodie, Z., Kane, A., \& Marcus, A. S. (2013) Essentials of Investments ( $9^{\text {th }}$ ed). McGrawHill Inc.

Chen,J.,Hong. H.,Huang.M., Kubik. J., (2004) "Does Fund Size Erode Mutual Fund performance? The Role of Liquidity and organization". The American Economic review. 94 (5), 1276-1302

Dewi.M., Ferdian.I., (2012) "Evaluating performance of Islamic Mutual Funds in Indonesia and Malaysia". Journal of Applied Economics and Business Research JAEBR, 2(1), 11-33

Drew, M. E., Stanford, J. D., \& Veeraraghavan, M. (2002) "Efficiency With Costly Information: A Study of Australian Wholesale Superannuation Fund Performance". Economic Analysis \& Policy. 32 (1), 35-47.

Elton, E. J., Gruber, M. J., Das, S., \& Hlavka, M. (1993) "Efficiency With Costly Information: A Reinterpretation of Evidence from Managed Portfolios". The Review of Financial Studies. 6 (1), 1-22.

Fama. E, French.K, (2010) "Luck versus Skill in the Cross- Section of Mutual Fund Returns". The Journal of Finance. LXV (5), 1915 - 1947

Goel, S., Mani, M., \& Sharma, R. (2012) "A Review of Performance Indicators of Mutual Funds”. International Refereed Research Journal. 3, Issue 4(1), 100-107.

Gumilang, T. F., \& Subiyantoro, H. (2008) "Reksadana Pendapatan Tetap di Indonesia: Analisis Market Timing dan Stock Selection - Periode 2006-2008”. Jurnal Keuangan dan Moneter; Badan Kebijakan Fiskal; Departemen Keuangan. 11 (1), 114-146.

Indro, D. C., Jiang, C. X., Hu, M. Y., \& Lee, W. Y. (1999) "Mutual Fund Performance: Does Fund Size Matter?", Financial Analysts Journal. 55 (3), 74-87. 
Investment Company Institute. (2006) Understanding Investor Preferences for Mutual Fund Information. United States of America.

Ippolito, R. A. (1989) "Efficiency With Costly Information: A Study of Mutual Fund Performance". The Quarterly Journal of Economics. 104 (1), 1-23.

Khorana,A., Servaes H., Tufano,P. (2008) "Mutual Fund Fees Around the World". The Review of Financial Studies. 22 (3), 1281-1310

Lin, C. Y., \& Yung, K. (2004) "Real Estate Mutual Funds: Performance and Persistence". The Journal of Real Estate Research. 26 (1), 69-93.

Ling, L. (2011) “A Life Cycle Analysis of U.S. Mutual Funds". International Review of Accounting, Banking, and Finance. 3 (4), 1-24.

Lohana, P. (2013) "Performance Evaluation of Selected Mutual Funds". Pacific Business Review International. 5 (7), 60-66

O’Neal, E. S., \& Page, D. E. (2000) "Real Estate Mutual Funds: Abnormal Performance and Fund Characteristics". Journal of Real Estate Portfolio Management. 6 (3) 239247.

Otoritas Jasa Keuangan. (2014) Statistik Pasar Modal Juli Minggu - 4. Jakarta: Otoritas Jasa Keuangan.

Petajisto, Antti (2013) “Active Share and Mutual Fund Performance". Financial Analyst Journal , 69 (4) CFA Institute

Philpot, J., Hearth, D., Rimbey, J. N., \& Schulman, C. T. (1998) "Active Management, Fund Size, and Bond Mutual Fund Returns". The Financial Review. 33, 115-126.

Qamruzzaman ACMA (2014) "Comparative Study on Performance Evaluation of Mutual Fund Schemes in bangladesh: An Analysis of Monthly Returns". Journal of Business Studies Quarterly, 5 (4), 190-209

Reilly, F. K., \& Brown, K. C. (2006) Investment Analysis and Portfolio Management $\left(8^{\text {th }}\right.$ ed $)$. Thomson South-Western.

Rudiyanto. (2014) Reksa Dana Saham: Trillion Club VS Billion Club. Februari 25, 2015, http://rudiyanto.blog.kontan.co.id/2014/08/29/reksa-dana-saham-trillion-club-vsbillion-club/

Sahoo, D., \& Sharma, N. K. (2008) "Performance Evaluation of Indian Mutual Fund Industry: A Case Study". GITAM Review of International Business, 1(1), 100-118.

See, Y. P., \& Ruzita, J. (2012) "Fund Characteristics and Fund Performance Evidenceof Malaysian Mutual Funds". International Journal of Economics and Management Sciences, 1 (99).

Sharpe, W. F. (1966) "Mutual Fund Performance". The Journal of Business. 39, 119-138.

Sing, T. C. (2007) "Effects of Expenditures and Size on Mutual Fund Performance". Singapore Management Review. 29 (1), 31-45.

Tim Studi Biaya dan Komisi Reksa Dana. (2010) Laporan Studi Biaya dan Komisi Reksa Dana. Jakarta: Kementerian Keuangan Republik Indonesia - Badan Pengawas Pasar Modal dan Lembaga Keuangan.

Undang-Undang Republik Indonesia Nomor 8 Tahun 1995 tentang Pasar Modal. Jakarta.

Vijayakumar, N., Muruganandan, S., \& Chandra, S. R. K. (2012) "The Relationship Between Fund Performance and Fund Characteristics: Evidence from India". The IUP Journal of Applied Finance. 18 (2), 5-18.

Waelan. (2009) "Persistensi Kinerja Reksa Dana Saham di Bursa Efek Indonesia". Jurnal Akuntansi \& Auditing Indonesia. 13 (2), 221-230. 
Wibowo, A. (2011) "Pengaruh Variabel Makro Ekonomi Terhadap Kinerja Reksadana Pendapatan Tetap di Indonesia". Jurnal Akuntansi, Manajemen Bisnis, dan Sektor Publik. 7 (2), 163-182.

Winingrum, E. P. (2011) “Analisis Stock Selection Skills, Market Timing Ability, Size Reksa Dana, Umur Reksa Dana, dan Expense Ratio Terhadap Kinerja Reksa Dana Saham yang Terdaftar di Bursa Efek Indonesia Periode Tahun 2006-2010”. Skripsi Diterbitkan. Universitas Diponegoro, Semarang. 